University of Montana

ScholarWorks at University of Montana

$1-1996$

\title{
Age-Biased Spring Dispersal in Male Wild Turkeys
}

\author{
A. V. Badyaev \\ W. J. Etges \\ Thomas E. Martin \\ University of Montana - Missoula, tom.martin@umontana.edu
}

Follow this and additional works at: https://scholarworks.umt.edu/wildbio_pubs

Part of the Life Sciences Commons

Let us know how access to this document benefits you.

\section{Recommended Citation}

Badyaev, A. V.; Etges, W. J.; and Martin, Thomas E., "Age-Biased Spring Dispersal in Male Wild Turkeys" (1996). Wildlife Biology Faculty Publications. 35.

https://scholarworks.umt.edu/wildbio_pubs/35

This Article is brought to you for free and open access by the Wildlife Biology at ScholarWorks at University of Montana. It has been accepted for inclusion in Wildlife Biology Faculty Publications by an authorized administrator of ScholarWorks at University of Montana. For more information, please contact scholarworks@mso.umt.edu. 


\title{
Age-biased Spring Dispersal in Male Wild Turkeys
}

\author{
Alexander V. Badyaev, ${ }^{1,3}$ William J. Etges, ${ }^{1}$ AND Thomas E. MarTin ${ }^{2}$ \\ ${ }^{1}$ Department of Biological Sciences, University of Arkansas, Fayetteville, Arkansas 72701, USA; and \\ ${ }^{2}$ Montana Cooperative Wildife Research Unit, University of Montana, Missoula, Montana 59812, USA
}

In polygamous animal species, the reproductive component of male fitness largely is determined by the number of females to which they can gain access (e.g. Wright 1946). Access to females often is strongly influenced by the possession of high-quality breeding or display grounds by males (Weatherhead and Robertson 1977). For animals that move between winter and breeding areas, access to high-quality breeding or display grounds can be determined by timing and distance of such movements, but ability to hold highquality sites could be determined by local familiarity, as well as social and physiological status (Greenwood 1980, Johnson 1986, Johnson and Gaines 1990, Pärt 1994, Tsuji et al. 1994).

Early dispersal and short-distance movements should allow access to best sites and dominant individuals should be expected to exhibit such movement behaviors. Moveover, shorter dispersal can enhance the survival component of fitness because it often reduces potential costs of increased mortality risk with dispersal distance (e.g. Johnson and Gaines 1990). Subordinates, however, may be expected to disperse longer distances and move more within display areas because it takes them longer and more movement to find suitable areas from which a dominant individual will not exclude them. Here we examine this dominance hypothesis.

Wild Turkeys (Meleagris gallopavo) are especially suitable for study of potential effects of dominance status on dispersal and movement patterns. They are polygynous and, in females, nest-site selection precedes mate selection (Healy 1992, Badyaev 1994). The social status in this species is largely set by age; young males are subordinate to older males and can be prevented from breeding by these older males (Healy 1992). In addition, the use of radiotelemetry allowed us to quantify female movements during spring dispersal and distribution of nesting areas (Badyaev et al. 1996).

We predicted that: (1) older males should disperse the shortest distance; (2) movements of older males should concentrate around suitable display grounds (i.e. around limited nesting areas; Badyaev et al. 1996) once they reach their display grounds, and should encompass a smaller area than subordinates; and (3) if movements of males in spring are influenced by displaying activity, males are expected to move more and farther in later parts of the breeding season when

\footnotetext{
${ }^{3}$ Present address: Department of Biological Sciences, University of Montana, Missoula, Montana 59812, USA.
}

female renesting and breeding receptiveness causes changes in distribution of females.

Methods._Our study was conducted during 19921993 in the Ozark National Forest in northern Arkansas. The study site was flat-topped hills (elevation to $746 \mathrm{~m}$ ) with narrow valleys. Dominant canopy species included white oak (Quercus alba), northern red oak (Q. rubra), post oak ( $Q$. stellata), shagbark hickory (Carya ovata), and shortleaf pine (Pinus echinata). For a detailed description of the study site, see Badyaev (1995). All birds were captured using cannon nets on pre-baited sites distributed throughout the study area. All captured birds were fitted with $120 \mathrm{~g}$ backpackstyle radio transmitters and released at capture sites. Most of the 35 radio-tagged males were located once every four to five days, although more frequent locations and visual observations also were recorded. Only birds with 15 or more recorded locations were used to calculate home ranges (for details of telemetry protocol, see Badyaev et al. 1996).

Females initiated $80 \%$ of first nests by 1 May in both years. Thus, the period prior to 2 May is referred as "early" as opposed to "late," which extends from 2 May to 2 June. Successive locations separated by more than 2 days but less than 10 days were statistically independent (e.g. Swihart and Slade [1985] test for two-day intervals; $\left.t^{2} / r^{2}>1.85, P<0.05\right)$ regardless of time lags between them. Observations separated by five days were used for interlocation distance analyses. The display range was defined as the home range occupied from 1 April through 15 June. This time interval was based on female nest-initiation phenology (Badyaev 1994). Dispersal distance was defined as the distance from harmonic mean of home range used in February to harmonic mean of display range. Partial area was calculated as sum of areas of all polygons drawn around centers of activity divided by the total area of single polygon of range occupied by an animal (Kenward 1990). Home-range estimates, interlocation distances, and associated statistics were computed using RANGES IV software (Kenward 1990; for details, see Badyaev et al. 1996). Neither morphological measurements nor dispersal parameters differed between study sites or years (ANOVA, all $P>$ 0.3 ). We used the criteria of Kelly (1975) and Steffen et al. (1990) to classify males into SY (second year after hatching), TY (third year after hatching), and ATY (after third year since hatching) age groups.

Results. -ATY males dispersed shorter distances than either SY or TY males (Kruskal-Wallis test, $X^{2}=7.45$, $\mathrm{df}=2, P<0.05$; Table 1). Dispersal distances of $\mathrm{SY}$ and $T Y$ males were not significantly different $\left(X^{2}=\right.$ $3.42, P=0.12$ ). Heavier SY males dispersed shorter 
TABLE 1. Descriptive statistics ( $\bar{x} \pm \mathrm{SE}$, with $n$ and range in parentheses) of spring-dispersal and home-range estimates of male Wild Turkeys in the Arkansas Ozarks, 1992-1993.

\begin{tabular}{lccc}
\hline \hline & \multicolumn{3}{c}{ Age category } \\
\cline { 2 - 4 } \multicolumn{1}{c}{ Parameter } & $\mathrm{SY}$ & $\mathrm{TY}$ & ATX \\
\hline Spring dispersal $(\mathrm{km})$ & $5.1 \pm 1.0(12,1.1-12.6)$ & $6.8 \pm 1.4(17,0.5-22.2)$ & $2.6 \pm 0.7(6,0.4-4.7)$ \\
Harmonic-mean range $\left(\mathrm{km}^{2}\right)$ & $18.9 \pm 7.9(5,2.5-36.7)$ & $1.7 \pm 0.5(9,0.4-4.2)$ & $0.38(1)$ \\
Multinuclear polygon $\left(\mathrm{km}^{2}\right)$ & $6.9 \pm 1.6(7,2.1-12.7)$ & $3.3 \pm 0.9(11,0.9-10.8)$ & $0.5 \pm 0.3(3,0.2-0.8)$ \\
Convex polygon $\left(\mathrm{km}^{2}\right)$ & $10.7 \pm 2.8(7,2.1-18.9)$ & $4.9 \pm 1.4(11,0.7-14.3)$ & $0.9 \pm 0.05(3,0.92-1.0)$ \\
\hline
\end{tabular}

- Harmonic-mean estimate, multinuclear polygon by clustering, and convex polygon methods based on $90 \%$-probability polygons.

distances, and body mass in spring explained $59 \%$ of the variation in spring dispersal distance in this age class (linear regression, $F_{1,12}=14.2, P<0.005$ ). Dispersal distances of TY and ATY males did not correlate with body mass (both $P>0.2$ ).

Display ranges of TY and ATY males were significantly smaller than those of SY males (Kruskal-Wallis test, $X^{2}=8.35, P=0.01$; Table 1 ). This difference was most apparent when harmonic-mean estimates of display range were used $(P<0.001$; Table 1$)$. Males of different ages used display ranges differently (Fig. 1). Partial-area estimate differed between age classes (Kruskal-Wallis test, $X^{2}=3.61, P=0.06$ ) and averaged $0.49 \pm$ SE of $0.13(n=10$, range $0.11-1.0)$ for adults (TY and ATY males combined) and $0.79 \pm 0.13(n=$ 7, range 0.37-1.00) for SY males. Adult-male use of range was concentrated around several centers of activity ( $\bar{x}=1.8 \pm 0.2)$, but $S Y$ male range use was less restricted to particular areas. Range estimates for subadults increased with almost every additional observation because birds frequently ventured into previously unvisited areas (Fig. 1).

For SY males, distances between successive locations averaged $4.1 \pm 0.3 \mathrm{~km}$ late in the season and were significantly longer than $2.2 \pm 0.1 \mathrm{~km}$ distances early in the season (pairwise $t$-test, $t=3.89, P=0.02$ ). However, there were no differences between early $\left(4.6 \pm 1.3 \mathrm{~km}^{2}\right)$ and late $\left(9.0 \pm 3.5 \mathrm{~km}^{2}\right)$ home ranges in this age class $(t=0.67, P=0.53)$. For adult males, distances between successive locations averaged 1.4 $\pm 0.4 \mathrm{~km}$ late in the season and $1.3 \pm 0.2 \mathrm{~km}$ early in the season, and were not significantly different $(t$ $=0.26, P=0.79$ ). Adult male home ranges used late in the season $\left(2.4 \pm 1.3 \mathrm{~km}^{2}\right)$ were significantly larger than home ranges used early in the season $(0.6 \pm 0.1$ $\mathrm{km}^{2} ; t=3.56, P=0.01$ ).

Discussion. - Our findings were consistent with predictions of the dominance hypothesis: late-winter home ranges of ATY males were closer to spring display grounds than were ranges of younger males. In addition, larger SY males, which presumably are dominant over smaller SY males, also dispersed shorter distances within this age group. Because suitable habitats for nesting are limited in our study area and prenesting dispersal of females is influenced by nesthabitat searching (Badyaev 1994, 1995), males benefit from being closer to such areas by assuring frequent encounters with females (see also Bradbury and Gibson 1983, Schroeder and White 1993). In the population under study, early nest initiation was the most important factor contributing to nest survival (Badyaev 1994). Thus, males that reach spring display grounds earliest profit by mating with early-nesting females.

Adult males occupied smaller display home ranges than did SY males (see also Hoffman 1991). Adultmale home-range use was more heterogeneous, which possibly reflects an uneven distribution of suitable nesting areas of females (Badyaev 1994, 1995, Badyaev et al. 1996). Adult-male movements within their display ranges were more restricted than those of SY males, potentially because nondisplaying SY males experience reduced aggression from older conspecifics when moving among display grounds (e.g. Healy 1992). Adult males showed considerable fidelity to display sites within the breeding season (Fig. 1). Bergerud (1988) and Phillips (1990) also speculated that female forest grouses preferred males showing the

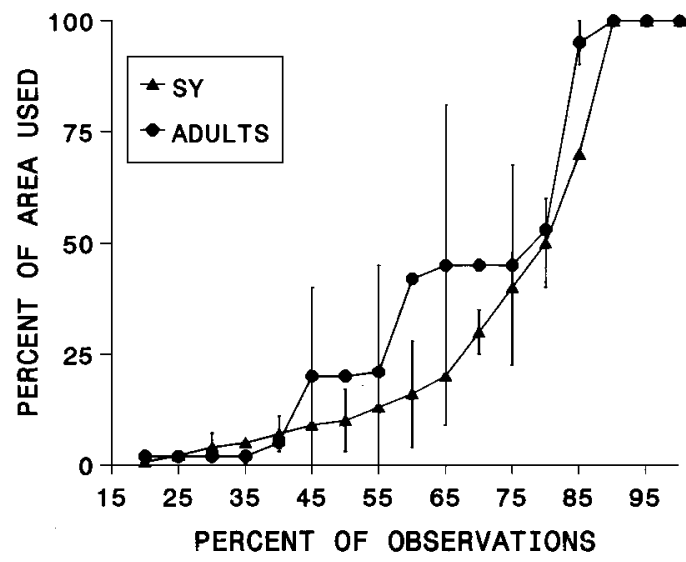

Fig. 1. Patterns of display range use in SY $(n=6)$ and adult (TY and older; $n=8$ ) male Wild Turkeys. SE shown for every $[20+10 n]$ percentage of observation for SY males, and for every $[25+10 n]$ percentage of observation for adult males. 
most predictability in display behavior when near nesting grounds. Male fidelity to displaying sites contributes to maintaining safe distances between female nests and male display sites, ensuring that males will not follow females to their nesting areas, thereby making them more conspicuous to predators (Bergerud 1988).

Wild Turkey males of all examined age groups increased their movements later in the season. The observed pattern is consistent with our prediction and could result from a decline in availability of receptive females and changes in the previously established hierarchy in breeding areas as a result of human disturbance (e.g. hunting). In addition, more areas became suitable for nesting later in the season (Badyaev 1995) and, therefore, female distribution was not so restricted as it was early in the season.

Acknowledgments. - We are grateful to D. Frick, D. Hasenbeck, A. Hodgson, T. Lane, and K. Teter for help with the fieldwork. We thank F. C. James and J. E. Johnson for helpful discussion. This paper was significantly improved by comments from A. T. Bergerud, G. D. Schnell, M. A. Schroeder, and an anonymous reviewer. The support of the Arkansas Game and Fish Commission and the University of Arkansas is gratefully acknowledged.

\section{LITERATURE CITED}

BADYAEV, A. V. 1994. Spring and breeding dispersal in an Arkansas population of Wild Turkeys: Causes and consequences for reproductive performance. M.Sc. thesis, Univ. Arkansas, Fayetteville, Arkansas.

BADYAEV, A. V. 1995. Nest habitat selection and nest success of eastern Wild Turkey in the Arkansas Ozark Highlands. Condor 97:221-232.

BADYAEV, A. V., W. J. ETGES, AND T. E. MARTiN. 1996. Ecological and behavioral correlates of variation in seasonal home ranges of Wild Turkeys in the Arkansas Ozarks. J. Wildl. Manage. 60 (in press).

BERGERUD, A. T. 1988. Mating systems in grouse. Pages 439-472 in Adaptive strategies and population ecology of northern grouse (A. T. Bergerud and M. W. Gratson, Eds.). Univ. Minnesota Press, Minneapolis.

BRadburY, J. W., AND R. M. Gibson. 1983. Leks and mate choice. Pages 109-138 in Mate choice (P. P. G. Bateson, Ed.). Cambridge Univ. Press, Cambridge.

GREENWOOD, P. J. 1980. Mating systems, philopatry and dispersal in birds and mammals. Anim. Behav. 28:1140-1162.

Healy, W. M. 1992. Behavior. Pages 46-65 in The Wild Turkey: Biology and management (J. G. Dickson, Ed.). Stackpole Books, Harrisburg, Pennsylvania.

HoffMaN, R. W. 1991. Spring movements, roosting activities, and home-range characteristics of male Merriam's Wild Turkey. Southwest. Nat. 36:332337.

JoHNSON, C. N. 1986. Sex-biased philopatry and dispersal in mammals. Oecologia 69:626-627.

JOHNSON, M. L., AND M. S. GAINES. 1990. Evolution of dispersal: Theoretical models and empirical tests using birds and mammals. Annu. Rev. Ecol. Syst. 21:449-480.

Kelly, G. 1975. Indexes for aging eastern turkeys. Proc. Natl. Wild Turkey Sympos. 3:205-209.

KENWARD, R. 1990. Ranges IV. Software for analyzing animal location data. Institute of Terrestrial Ecology, Wareham, United Kindom.

PART, T. 1994. Male philopatry confers a mating advantage in the migratory Collared Flycatcher, Ficedula albicollis. Anim. Behav. 48:401-409.

PhILlIPS, J. B. 1990. Lek behaviour in birds: Do displaying males reduce nest predation? Anim. Behav. 39:555-565.

SCHROEDER, M. A., AND G. C. WhITE. 1993. Dispersion of Greater Prairie Chicken nests in relation to lek location: Evaluation of the hot-spot hypothesis of lek evolution. Behav. Ecol. 4:266-270.

StEFFEN, D. E., C. Couvillion, AND G. A. HuRst. 1990. Age determination of eastern Wild Turkey gobblers. Wildl. Soc. Bull. 18:119-124.

SWiHART, R. K., AND N. A. Slade. 1985. Testing for independence of observations in animal movements. Ecology 66:1176-1184.

TsujI, L. J. S., D. R. Kozlovich, M. B. SoKolowsKI, AND R. I. C. HANSELL. 1994. Relationship of body size of male Sharp-tailed Grouse to location of individual territories on leks. Wilson Bull. 106: 329-337.

WEATHERHEAD, P. J., AND R. J. ROBERTSON. 1977. Harem size, territory quality, and reproductive success in the Red-winged Blackbirds (Agelaius phoeniceus). Can. J. Zool. 55:1261-1267.

WRIGHT, S. 1946. Isolation by distance under diverse systems of mating. Genetics 31:39-59.

Received 5 December 1994, accepted 26 June 1995. 